\title{
CITIZEN PARTICIPATION: A SUBURBAN SUGGESTION FOR THE CENTRAL CITY
}

\author{
Richard F. Babcock* and Fred P. Bosselman $\dagger$
}

Municipal building, zoning, and housing codes have traditionally been characterized by (I) centralized municipal administration and (2) comprehensiveness of their application within the political jurisdiction to which they are applicable. These distinctive features may be consistent with the goals of the residents of small, homogeneous suburbs. Within our large cities, however, these same characteristics explain much of the failure of such codes to come to grips with the problems of lower income residents of blighted neighborhoods.

It is the purpose of this paper to propose a line of examination that will question the relevance of these orthodox rules to current urban conditions and to suggest the testing of a system of code administration and enforcement in our big cities that is not bottomed on those two ancient premises.

\section{The NeEd for Decentralization}

A mass of literature has accumulated in the past few years advocating "citizen participation" as the latest tactic for solving the problems of deprived neighborhoods, now that public housing and urban renewal have "failed." These "People people" as Roger Starr might characterize them, ${ }^{1}$ urge us to emphasize the needs and desires of the people in each neighborhood and block rather than the needs of the city as a whole. They suggest that we adopt "the microscopic or detailed view."2

The methods that they have advanced for achieving participation in governmental affairs by residents of deprived neighborhoods unfortunately fall, for the most part, into two self-defeating categories.

The first might be called the "burn, baby, burn" theory. This holds that the urban establishment will never voluntarily pay any attention to poor people unless poor people make themselves obnoxious. To achieve this end various organizers, professional or otherwise, are employed to activate groups in support of particular issues, ${ }^{3}$ and to bring pressure to bear upon the city administration, through adversary methods ranging from noisome irritation to guerilla warfare.

*A.B. I940, Dartmouth College; J.D. 1946, M.B.A. 1951, University of Chicago. Member of the law firm of Ross, Hardies, O'Keefe, Babcock, McDugald \& Parsons, Chicago, Ill. Author, The Zonino Game (I966).

+ A.B. 1956, University of Colorado; LL.B. I959, Harvard University. Member of the law firm of Ross, Hardies, O'Keefe, Babcock, McDugald \& Parsons, Chicago, Ill.

${ }^{I}$ Starr, The People Are Not the City, in American Soc'x of Planning Officials, Planning 1966, at 125 (xg66).

2. Jacobs, The Death and Life of Great American Cities 439 (Ig6r).

3 The leading text is, of course, S. Alinsky, Reveilze For Radicals (r945). 
The second tactic-often a self-conscious riposte to the first-might be called the "figurehead" method. This calls for the placing of a number of "leading" residents from deprived areas on advisory boards and commissions where they can meet and nod their heads when their sponsors tell them what is good for them, ${ }^{4}$ while the rest of the populace is overwhelmed by a swarm of social workers skillfully trained in head-patting. ${ }^{5}$

Neither of these strategies offers the citizen of the urban neighborhood real participation in the actual decision making process. At a recent conference in Chicago, Daniel Watts, editor of Liberator, a "new left" magazine, bluntly described the failure of the figurehead method: ${ }^{6}$

The negro preacher has been the self-appointed leader of the community and the white power structure of the city would like to deal with him. But this doesn't get through to the "soul brothers" who could get the idea to burn the community down. You've got to get them to feel that this is their community and it would be their community that they would put to the torch.

The "burn, baby, burn" method may achieve a few additional neighborhood swimming pools, tot lots, and similar short-range goals, but at what cost? ${ }^{7}$ The technique creates so much antipathetic reaction that it carries the seeds of its own destruction by a fierce response from the majority.

Neither of these responses to the growing restlessness in our cities offers a constructive solution to what Richard Goodwin has recently called "the most troubling political fact of our age: ... [the] swift and continual diminution in the significance of the individual citizen, transforming him from a wielder into an object of authority." Nor are traditional political processes satisfactory means of obtaining citizen participation. It may be true, as one politician suggested, that every good precinct captain is an ombudsman. The rub is that in an age when a real understanding of government requires familiarity with electronic machines as well as political machines it is hard to find good precinct captains. The distance between the increasing complexity and professionalism of City $\mathrm{Hall}$ and the malaise of the poor citizen has widened appreciably since the days of the Curleys and Crumps." As David Hunter puts it: "Slum people are out!"10

\footnotetext{
- See, c.g., City Pzanning Associates, Suggestions for Enligting Citizen Participation in Urban Renewal (1962), a guide for the creation of such groups; ARthur D. LitTle, Inc., Strategies For Shaping Model Cities 22-27 ( 1967 ).

'See, e.g., David \& Lewis, Citizen Participation, 20 J. Housrng 472, 474 (1963), discussing the creation of tenant organizations in public housing in New York City: "The most helpful relationship between authority staff and tenant organization would seem to lie in an educational and training role." (Original in italics.) Compare G. Orweli, The Road To Wigan Pier 70-73 (Ist Am. ed. I958).

- Chicago Daily News, June 7, I967, at 9, col. I.

${ }^{7}$ See generally Twomey, Citizen Participation, 20 J. Housing $46_{3}$ ( Ig63). $_{3}$ ).

${ }^{8}$ Goodwin, The Shape of American Politics, Commentary, June I967, at 25. Compare W. Lippman, The Phantom Public I74-83 (I925).

'See R. Wood, Suburbia 165,197 (1959). This is not to deny that many municipal governments have a good record of employing residents of deprived neighborhoods in city jobs, but commuting to city hall creates little feeling of participation in the neighborhoods.

10 D. Hunter, The Siums, Challenge and Response 221 (I964).
} 
Real citizen participation is possible-in an era when HUD has replaced Hagueonly if real governmental power is delegated to the neighborhood level. It is past time that we begin directing imaginative debate toward the formulation of a legal and administrative system that may achieve real decentralization of governmental power in our large cities and still leave to the central city government control over those features of the urban environment that require centralized administration.

It is significant that precisely such an exercise in the re-allocation of power is now going on in the metropolitan areas outside the central city. The suburbs, large and small, long accustomed to wielding all the powers of government, are faced with demands that they divest themselves of control in those areas of power where the facts of our untidy environment require a wider consensus of decision making. In the case of the metropolitan area the transference of power is upward to state and regional agencies, impelled by the inability of the suburbs to deal individually with the exploding problems of transportation, the pollution of our air and water, our shriveling open spaces, and overwhelming densities. In the case of the central city, however, a similar and consistent re-appraisal requires the transfer of some power downward to the individual neighborhood. In each case, the hard job is to make a reasonable allocation of power that will recognize the legitimate interests of the neighborhood (or suburb) on the one hand, and the city (or region) on the other.

The enforcement and administration of housing, zoning, and building codes and related ordinances may be a fair area in which to test out the feasibility of such a delegation of power, for in these spheres of government all would have to agree that those regional neighborhoods, the suburbs, should retain considerable administrative authority. No more is here proposed to be given to the city's neighborhoods than would be left to the suburbs by even the most intransigent regionalist.

Before delving further into the theoretical advantages of this type of decentralization, we propose to suggest a way in which such decentralization might operate in practice.

\section{II}

\section{Decentralization: A Proposal}

Under our hypothetical system the city would be subdivided into administrative districts following historic neighborhood boundaries, probably with no less rational bases than are apparent in many suburban municipal boundaries. (Certainly the variations in population and "motivation" among these "suburbs in the city" would not be significantly greater than now exist among such suburbs as Winnetka and Robbins, Illinois, each of which enjoys substantially all the powers vested in municipal corporations.)

Within each of the districts of the city in which the technique is adopted would be chosen a Board of Compliance and Appeal made up of residents of the 
neighborhood.11 The neighborhood Board would have three types of powers: it would set standards, it would enforce them, and it would grant variations from them. The standards created by the Board and its administration of them would be subject to overall policies and guidelines laid down by the central administration.

Each Board would have its own staff of engineers, planners, and attorneys who would be available to provide information on codes to the residents of the neighborhood and to conduct inspections of housing units for code violations. The staff could also conduct schools on housing maintenance for under-urbanized tenants and fledgling landlords, similar to the "traffic schools" so commonly used in modern traffic courts, ${ }^{12}$ and could engage in other advisory and educational activities. ${ }^{13}$

The neighborhood Board could play a major role in code enforcement. When violations are found, the offender would be brought before the neighborhood Board as the first step in obtaining compliance. The Board would set a timetable for making repairs and would offer advice and supervision. The neighborhood Board would be better able than any housing court judge to tell whether a property owner is making a bona fide effort at compliance with the codes, and can far more easily ascertain the number of families living in a building than can any building department-a problem of increasing importance in view of the new restrictions on housing inspection laid down by the United States Supreme Court. ${ }^{14}$ The Board, not just the city, would have the power to seek judicial implementation of its decisions, ${ }^{15}$ and in chronic cases of noncompliance a court order might be obtained making the Board the receiver of the property ${ }^{16}$

There are many subjects of code regulation that could be varied from neighbor-

21 The city might well choose to begin use of the technique on an experimental basis in 2 limited number of neighborhoods, retaining for the rest of the city the existing city-wide code administration which would be gradually phased out as new neighborhood boards are phased in. It is recognized, of course, that constitutional problems of equal protection, as well as numerous questions of state law, will need to be considered in instituting this type of system. Cf. the Texas statute authorizing the City of Houston to sue to enjoin violations of private covenants. Tex. Rev. Crv. Stat. ANN. art. 947a-I (Supp. 1966). See also the prezoning era techniques by which the residents of particular neighborhoods were given governmental authority to control new construction through the creation of restricted residence districts. E.g., State ex rel. Twin City Bldg. \& Inv. Co. v. Houghton, I44 Minn. I, I74 N.W. 885, I76 N.W. I59 (I920). The State of Washington has recently enacted a statute permitting a form of consolidation of municipalities in which each former municipality retains separate powers in regard to zoning, subdivision control, and "comprehensive planning." Ch. 73, [1967] Wash. Laws.

${ }_{12}$ Pionecring in this type of educational treatment is the Baltimore Housing Clinic. See generally Bateman \& Stern, Housing Clinic for Code Violators, 23 J. Housing 203 (I966); Note, Enforcement of Municipal Housing Codes, 78 Harv. L. Rev. 80x, 825-26, 859 (1965).

13 The use of neighborhood information centers in which municipal employees are station in the neighborhoods to advise and assist the residents has received enthusiastic and rapid acceptance in the past few years. See A. Kakn, Neighoorhood Inforanation Centers: A Study and Some Proposais (ig66). The present suggestion would expand on this idea by giving the neighborhood centers greater power, and giving the residents of the neighborhood the immediate supervision of them.

14 Camara v. Municipal Court, $3^{8} 7$ U.S. 523 ( $(967)$. See also R. POUNd, Social Control Through LAw 53-55 (I942).

${ }_{15}$ In 2 number of states zoning boards now have the right to litigate independent of the city. See, e.g., Dion v. Board of Appeals of Waltham, 344 Mass. 547,183 N.E.2d 479 (1962).

${ }^{16}$ See generally Gribetz, New York City's Receivership Law, 21 J. Housing 297 (1964); Note, supra note I2, 2 t 828-30. 
hood to neighborhood, as the citizens of the neighborhood may choose. Consider the control of housing density: the number of housing units to be permitted per acre. The city's interest in the gross density of its component parts is indisputable, though no more than is the region's concern over the densities of the multitude of municipalities of which it is made up. Control over housing density is crucial in the planning of transportation, recreation, and other public facilities. Trying to plan highways or sanitary systems for regions containing communities which may have five-acre lots today and quarter-acre lots tomorrow makes transportation or sanitary planning more of an intellectual exercise than a meaningful occupation. Only if the governmental unit that plans the highways or sewers also has a voice in the control of the overall number of housing units per acre could economical planning of public facilities be achieved.

But the proposition that gross density of population is not a matter for neighborhood control should not necessarily result in a legal system that leaves a neighborhood with no voice in whether Mrs. Schultz should be able to convert her two-family dwelling into a four-family flat. For example, within general policies set by the city (e.g., that housing in a particular neighborhood should not exceed an average of $x$ units per acre, or that in the next ten years the population of the neighborhood should not increase by more than 20,000), the neighborhood Board rather than City Hall could be given the power to pass upon specific proposals by would-be builders or landlords. Thus the actual decisions as to where and how many new housing units would be permitted, and whether remodeling and conversions of old housing would be allowed, could be delegated to the neighborhood Board, while the city retains control over the overall number of housing units that would be permitted in the neighborhood as a whole. Of course the scope of the neighborhood Board's discretion would need to be kept within limits of city-wide concern over the efficiency and availability of major public services such as sewer and water facilities and traffic.

Another area of potential decentralization is the administration of "open space" requirements. Why must every $\mathrm{R}-2$ single-family district or every $\mathrm{R}-5$ multiplefamily district, wherever located in the city, have the same setbacks and side yards? "More Open Space for what?" as Jane Jacobs asks. ${ }^{17}$ And why must departures from those uniform patterns-probably originally copied out of some other city's ordinance-require a petition to City Hall? Is there any reason why the residents outside an immediate neighborhood should care how much open space is provided on each private parcel, assuming that overall density is controlled? Despite Lewis Mumford's claim that the residents of Park Avenue, being deprived of open space, live in a slum and don't know it, ${ }^{18}$ it seems perfectly appropriate to let the citizens of Park Avenue or Brooklyn Heights or East Harlem determine the extent to which open space

\footnotetext{
${ }^{17} \mathrm{~J}$. JacoBs, supra note 2 , at 90.

${ }^{18}$ L. Munford, The City In History 428 (I96I). See also H. Kobbe, Housing and Regional Planning I9 (I94I).
} 
must be maintained on individual lots as long as a larger jurisdiction controls the overall density of the neighborhood as a whole.

Then there is the familiar and often litigated problem of "home occupations." Should Mrs. Jones be allowed to run a beauty shop in her basement? Should a real estate broker be allowed to erect an advertising sign in front of his home? There is no reason why anyone at Boston City Hall knows more about these questions than the residents of the neighborhoods of Allston or Roxbury. And would not the municipal officials be happy to free themselves from the responsibility for resolving these emotionally charged but basically petty quarrels?

As a last example, consider the control of architectural design of individual housing structures, an issue which appears to be of great importance to many suburbs and which may become of more interest to deprived neighborhoods in central cities as the paint manufacturers and social psychologists assume a more significant role in urban renewal. There are, of course, selected locations where the control of architecture and design has major regional impact-the preservation of the aesthetic beauty of the Potomac, the maintenance of the charm of the Vieux Carre, or the creation of "gateway" districts to give arriving travelers an unobstructed view of the San Francisco skyline. But in most locations architectural style has no impact outside the immediate neighborhood, and its regulation (if any) could best be left to the neighborhood. 10

A few aesthetes may insist that the residents of neighborhoods, deprived or otherwise, lack the keen artistic sense necessary to provide meaningful standards of architectural design or decoration. We suggest that in these days when pop art and "indigenous architecture" are so fashionable it would be difficult to deny anyone the right to become his own judge of artistic merit. "The human being is an unproclaimed architect," proclaims Charles Abrams; "the touch of a hundred hands can have the patina of humanity."20 One only needs to look at a few typical examples of public housing design to conclude that the neighborhood would be hard put to do worse than City Hall. ${ }^{21}$

The above illustrations are only a few of the many suggestions for experiment that could be given. The only missing link is an administrative and legal system for partial decentralization of code administration.

We should not be misunderstood. The authors are as aware as the reader of the host of difficult legal, administrative, and political hazards that such a scheme must

\footnotetext{
${ }^{10}$ See Babcock, Billboards, Glass Houses, and the Law, Harper's Magazine, April I966, at 20.

${ }^{20}$ C. Agrams, The Citr Is the Frontier 320 (1965). Lest this be thought to be purely an American phenomenon it should be noted that the Louvre recently featured an exhibition entitled "Selection des Collections de la Compaignie de l'Art Brut" consisting of art works created by "schizophrenic or psychopathic patients from special institutions" who are described by their patron, artist Jean Dubuffet, as "persons who are strangers to cultural milieus, have been preserved from their influences, and, for the most part, have had only a rudimentary education." THE NEw YoRkER, April 29, 1967, at 169-70. Ironically, many ghetto residents might feel that they also meet those criteria.

${ }^{21}$ See Mayer, Public Housing Architecture, I9 J. Housing 446 (1962).
} 
overcome. All we suggest is that an analysis be made, unhindered by traditional assumptions about the structure of city government, of all phases of the codes which control housing and land development to determine the extent of the impact of each phase of governmental control. Those aspects which have broad impact should be under broad control. Conversely, those powers which have no significant impact outside a small locality should be under local control. For such latter functions, enforcement and administration could be decentralized right down to the neighborhood level.

\section{III}

\section{The Limits of Decentralization}

There are, of course, many aspects of the traditional municipal codes that cannot and should not be delegated to the neighborhood level. These nondelegable features fall into two categories. First and most important are matters of indivisible city policy, and where such policies are involved the least to be expected from City Hall is that it articulate those policies that demand city-wide decisions. The planning profession is turning away from the mapped master plan showing specific locations of land use and toward the "policies plan" in which the city states the basic policies that should guide the particular location of land uses. ${ }^{22}$ Too often, however, these policies plans are being formulated in such ambiguous terms that they can be employed to justify almost any decision which subsequently proves to be expedient. Because the policies have no legal significance there is no compulsion to assure that their meaning is precise. However, if the city's planning policies were to be legal limitations on the powers of neighborhood Boards to set neighborhood standards and dispense variations from them, the pressure would be on the planners to formulate real policies in definitive fashion. The city's policies plan would then at last perform a useful function. ${ }^{23}$

The second area in which delegation of power to neighborhood boards should not be permitted is in regard to those code provisions which are so essential to the health and safety of the entire population that no variance from them should be permitted regardless of the desires of the local residents. The basic policies underlying the codes, involving such things as fire protection and public health, cannot be delegated to the neighborhood level.

It is easy, of course, to state the general proposition that overall policy matters and basic health and safety matters should not be delegated. The difficulty lies in actually drawing lines. Where does policy end and implementation begin? Which aspects

\footnotetext{
${ }^{22}$ Aschman, The "Policy Plan" in the Planning Program, in AMERICan Soc'y of Planning Oppicals, Planning 1963, at 105 (1963); Fagin, Planning for Future Urban Growth, 30 LAw \& Contemp. Prob. 9, 19 (I965); F. S. Chapin, Jr., URban Land Use Planning 349-54 (2d ed. 1965); American Soc'Y op Planning Officials, Policy Statements: Guides to Decision-Making (ASPO Planining Advisory Service Information Rep. No. 152, x96r).

${ }^{23}$ See Williams, Development Controls and Planning Controls: The View From 1964, in Procendings of the 1964 ANnual Conference of the American Institute of Planners 70, 78 (I964).
} 
of building codes are in fact designed to protect basic health and safety and which are attempts to protect union privileges or vestiges of long-forgotten purposes ? $^{24}$

For example, the desire to reduce costs of rehabilitation will need to be balanced against the concern of all residents of the city over adequate fire protection. Yet this relationship between neighborhood and city is a two-way street, and even some of those aspects of municipal codes that are often thought of as intimately related to health and safety may be susceptible to modification in individual neighborhoods. To alleviate the drastic problems of some deteriorating neighborhoods it may be necessary to sacrifice the ideal for the feasible, and the opportunity to try out new ideas in building construction should not be hamstrung by the reluctance to extend the experiment to all neighborhoods. ${ }^{25}$ The willingness of the United States Gypsum Corporation to experiment in Harlem with new techniques should not be frustrated by codes that know no difference between Harlem and Staten Island. ${ }^{26}$

Those who instinctively oppose any "weakening" of code requirements must face an undeniable fact of life. Our present codes are not effectively helping to remedy housing deterioration. In his recent testimony before the Ribicoff Committee, George Sternlieb emphasized that rigid code enforcement does not have uniformly desirable effects: $:^{27}$

The cry goes out for code enforcement, and code enforcement obviously is essential, but not uncommonly, when you put the screws on for code enforcement, what you

\footnotetext{
${ }^{36}$ Florida planning consultant Fred Bair described the origin of the common requirement that each dwelling unit have a minimum of 600 square feet:

You go up and talk to the American Public Health Association and say:

"Look-we've been reading this housing code of yours with considerable interest. Where did you come up with the figure that you had to have 6oo square feet of floor space in a house to be reasonably healthy, safe and moral-or whatever it is that you're trying to do with that regulation?" And they say, "Well-what was that again?" And you say, "Well, where did you get that 600 square foot figure?" "Well, gee, let's see-who was on that committee?" So you find out that Stu Chapin and so-and-so and so-and-so were on that committee in 1952 and they reached up and picked a figure out of thin air. This conclusion is inescapable. But because the figure was published by APHA, it became a religious symbol. And now you go into them and say, "Well, look-we've got air conditioning. We've got heating. We've got artificial light. Got any number of things that we didn't have generally in 1940 or 1950 or whatever. Does this change the picture?" And they say, "Well, no-it doesn't change the picture. It is printed right there-600 square feet." And you can pursue our symbols and shibboleths back to their origins. But because these things are universally worshipped now, the fact that the origins were a little weak doesn't make too much difference any longer.

R. Babcock, The Zoning Game i6 (I966).

${ }^{25}$ The feeling of being a guinea pig which might prevail if experimental techniques are imposed from city hall would be alleviated if a neighborhood board were to control the extent to which experimentation was to be permitted. Of course a number of constitutional and legal problems will have to be faced; for a summary of the legal problems of zoned housing codes, see NAT'z Ass's of Housing and Redevelopment Officinls, The Constitutionality of Housing Codes 43-45 (2d ed. I964).

${ }^{20}$ See address by H. Ralph Taylor, Assistant Secretary of the Department of Housing and Urban Development, 1967 Spring Conference of the Building Research Institute, May 3, 1967 (mimeo. ed. at 7).

${ }^{27}$ Hearings on the Federal Role in Urban Affairs Before the Subcomm. on Executive Reorganization of the Senate Comm. on Government Operations, 89th Cong., 2d Sess., pt. 8, at 1686 (1966). See also Comment, Building Codes, Housing Codes and the Conservation of Chicago's Housing Supply, 3I U. CHI. L. REv. I80 ( 1963 ).
} 
get are one of three patterns of conduct. One pattern is the one that you would really like. People fix up the parcel. That is fine. Another pattern is people basically avoiding the code one way or another. The third pattern is that of people basically abandoning the parcel, and, in a weak market, there is a tendency toward abandonment. There is a tendency toward burned-outs. . . .

If you do get code enforcement, not infrequently you get it at the cost of raising rents and driving the poor out. So we have a very complicated picture before us.

In his study of slum housing conditions in Newark, Mr. Sternlieb pointed out the failure of the codes to reach the real needs of the residents: "[A]dequate insect and rodent control, plumbing that works, paint, and general cleanliness may be much more significant to the inhabitants of a tenement, both physically and spiritually, than the existence of central heat and/or plaster walls."28 The slum resident lacks a feeling of identification with the code enforcement process in part because the codes appear arbitrary and mechanical. They are not his codes.

But if the residents of each neighborhood were given the power to set their own housing and building code standards, within relatively broad perimeters of health and safety criteria, and were given the power to enforce these standards and grant variations where appropriate, the codes and their enforcement would begin to be tailored to the actual needs of neighborhood residents. In this way a step would be taken toward the goal of, as Senator Joseph Clark has put it, "design[ing] cities so that the pattern of the city complements the individual's pattern of living."

IV

\section{Advantages of Decentralization}

It is a sardonic fact that the gripes of deprived neighborhoods are directed at both the severity of enforcement and the looseness of enforcement, and frequently simultaneously. The neighborhood Board would serve as a forum not only to enforce compliance but to dispense benefits. It would provide an arena for debate and decision making by low- and middle-income tenants and landowners that would be much more accessible to them than the distant and little understood machinery at City Hall.

One of the major difficulties of achieving any progress in slum neighborhoods

${ }^{28}$ G. Sternlieb, The Tenement Landiord 233 (Ig66).

${ }^{29}$ Clark, Planning for People, in American Soc'y of Planning Officials, Planning 1966, at 119 (1966). Carl Friedrich has summarized the idea very well: "[P]olicies deal with average acts of average persons. It is with reference to these that the judgment of the uncommon man is untrustworthy, just because he is an uncommon man." C. Friedrich, The New Image of the Common Man 37 (1950).

The importance of local initiative was well summarized by Pastor Leopold Bernhard, founder of the highly successful East Central Citizen Organization of Columbus, Ohio, in his testimony before the Ribicoff Committee. "Our experience... [is] that when we come with something from the outside, however good it is, it will not be received and it will not work as well as something that has been arrived at with the decision of the people." Hearings, supra note 27, pt. 9, at 2084 . As Henry Churchill said: "A city plan is the expression of the collective purpose of the people who live in it, or it is nothing." H. Churchil, The City is the People 186 (I945). 
is the sense of alienation the residents feel toward society. "They see life rather as unpatterned and unpredictable, a congeries of events in which they have no part and over which they have no control."30 The residents of slums feel that they lack "access" to the government in the sense that they are not confident of their ability to transmit their views to the city administration and have them taken seriously. "One of the greatest single problems of the people who live in the slums," Secretary Weaver has said, "is lack of knowledge, and that leads to fear."32 Decentralization of big city government offers a means of providing this access.

A larger degree of participation by slum dwellers in their local government should give them a greater sense of identification with the city government, and reduce their antagonism toward City Hall. As sociologist Marshall Clinard puts it, "A certain degree of decentralization of civic authority in the slums might result in greater support for government and thus help to overcome some of the apathy and hostility displayed by many slum dwellers."33

Decentralized code enforcement and administration should also help in overcoming the often prevalent hostility toward the city administration by the middle-class resident. This attitude is well summarized by the New York woman whose response to the city's proposal to change the name of Third Avenue was quoted by Bernard Frieden: "They should leave this city alone! They should keep their cotton-pickin' fingers off!" $" 34$

Another of the major benefits of decentralization of code enforcement and administration in large cities is that it would reduce the advantages now obtained by the large scale slum landlord who is able to develop or hire the expertise necessary to cope with the complexities of the central building department and housing court, and who is able to spread the costs of legal fees, fines, and the other overheads of his trade over a large number of units. The resident owner of a small apartment building finds dealing with these centralized agencies mysterious and expensive. ${ }^{35}$ But the opposite result would obtain if code enforcement and administration were handled at the neighborhood level. Then it would be the local landlord who would have more empathy with the administrators-now his neighbors and social equalswhile the large scale slumlord would have difficulty dealing with a number of

\footnotetext{
${ }^{30}$ U.S. Welfare Administration, Dep't of Health, Education, and Welfare, Low-Income Life Strues 3 (L. Irelan ed. I966).

${ }^{31}$ See J. C. Davies III, Neighborhood Groups and Urban Renewai igi (1966).

${ }^{32}$ Address by Robert Weaver, Secretary of the Department of Housing and Urban Development, Conference on the Rights of Tenants, Washington, D.C., Dec. 9, I966 (mimeo. ed. at 4).

as M. Clinard, Slumis and Community Development 129 (ig66).

as. Frieden, The Future of Old Neighborhoods 124 (I964).

${ }^{35}$ In some cases he may also feel that the city's building department is actually hostile toward him. See Housing and Redevelopment Bonrd, Neighborhood Conservation in New York City 88 (1966). David Hunter suggests that the resentment of the residents of underprivileged areas toward what they often feel to be discriminatory imposition of penalties might be alleviated by obtaining "the support and cooperation of the residents of a slum area in the inspection process and follow-up." D. HuNTER, supra note xo. See also Davison, On the Effects of Communication, 23 Pub. OpINion Q. 343, 360 (1959).
} 
separate neighborhood agencies with whom he would have less "kinship" than with the central city leaders. ${ }^{36}$

The decentralization of any part of code enforcement and administration is not a simple matter. Comprehensive study of the detailed legal and administrative problems in each jurisdiction would be required, and state legislation would be needed to implement the needed changes. After some experimentation, however, there is no reason why a practical and workable method of delegation of authority could not be feasible.

\section{V}

\section{Parallels in the Suburbs}

Is increased citizen participation feasible in view of the increasing complexity of government in our mushrooming metropolitan areas?

It is one of the ironies of land development policy in our era that the strident cry within the neighborhoods of our big cities for dispersion of power arises at the same time as the emergence of a justified criticism of the fractured and dispersed condition of land use controls in the suburban areas due to the multiplicity of political jurisdictions. In the outer parts of the metropolitan area the suburban duchies are manning the battlements to ward off the attacks of the regionalists who seek to transfer control over schools, air pollution, open space, and other traditional concerns of suburban governments to larger governmental units. The "big picture" planners urge us to "conceive Ecumenopolis, the universal city" and to institute "a unity of command for the broadest possible urban area so that we have unified programs, plans, and implementation efforts." 37 Both the states and the federal government are relentlessly chipping away at the suburb's exclusive powers over the control of land use.

Nevertheless, the pressure for increased citizen participation in the big cities parallels the equally strong drive toward state and regional control of land-use issues that have a metropolitan impact, and both of these apparently contradictory goals of centralized policy-making and local citizen participation can be rationalized into one logically consistent policy. To put it more bluntly, the same authors who have previously urged a reduction in local control of housing in the suburbs can now urge a greater localization of housing control in the central city. ${ }^{38}$

The reason lies in the nature of our existing legal system of local government. The central city is a conglomeration of many neighborhoods, each of which may well attain as much social and historic unity as the average suburb. The suburb, however,

${ }^{30}$ See G. Sternlieb, supta note 28 , at $137-4 \mathrm{I}$.

s7 C. A. Doxiadis, Urban Renewal and the Future of the American City 131 (1966). See also L. MUMFORD, supra note 18, at 576: "The final mission of the city is to further man's conscious participation in the cosmic and the historic process."

${ }^{38}$ See Babcock \& Bosselman, Suburban Zoning and the Apartment Boom, III U. PA. L. REv. xofo (1963). 
enjoys virtually absolute control over the location, size, style, and characteristics of housing and other land uses, while an equivalent neighborhood in the city has no control whatsoever over its own affairs. Usually the sole requirement for the exercise of such control is that a group of people in a contiguous geographical area shall have formed a municipal corporation. It's all or nothing. As with so many aspects of land use control, only black and white solutions are available and there is no middle ground. ${ }^{38}$

If even those who most outspokenly advocate regional solutions for regional problems would agree that only a limited number of basic policies should be enacted at the regional level, and that most of the actual implementation and decision making relating to specific parcels of land should be retained by the suburbs, would it not be consistent to apply a similar logic in the communities within our central city and to conclude that some of the powers now centralized in the city administration should be delegated back to the neighborhood level?

In our opinion the type of decentralization advocated in this article is consistent with the view that the states should exercise greater policy-making authority over problems of regional impact. ${ }^{40}$ It seems apparent to us that this proposition is fully consistent with the principle that policies should be formulated at the level of their impact. Policies which affect the entire nation should be formulated on the national level; policies which affect a whole state should be formulated at the state level; decisions which affect only the neighborhood should be made at the neighborhood level. And it matters not whether the neighborhood be an incorporated suburb or an undivided portion of a central city. Under this banner the Jacobses and Doxiadises could join hands and get on about improving the neighborhood as well as the region rather than criticizing each other.

No one would seriously claim that neighborhood participation in local code administration and enforcement would be successful in solving all of the problems of our urban areas. But, as Peter Blake recently pointed out, nobody guaranteed that space exploration would be successful before it was tried: $:^{41}$

To achieve that ambitious goal, much planning at Cape Kennedy had to be based on educated guesswork-before all the facts were in. As a result, a great deal of time was saved-the kind of time that is often wasted in attacks on urban problems, because no one is willing to take a chance until every theory has been tested over and over again.

Our federal system offers an ideal laboratory for experimentation with methods of solving urban affairs. The time has come to initiate such experiments in the decentralization of local governmental power within the large cities. What is claimed to be good for the suburban goose should be tried with the urban gander.

\footnotetext{
${ }^{30}$ See Bosselman, The Third Alternative in Zoning Litigation, 17 ZonIng Digest 73, II3 (1965).

${ }^{\circ}$ See R. BABcock, supra note 24, at 159-66.

¿1 Blake, Cape Kennedy, Architectural Forum, Jan.-Feb. I967, at 50, 59.
} 